\title{
Senior Teaching Fellows: Renewal and Professional Development
}

\author{
Libby V. Morris
}

Published online: 29 November 2011

(C) Springer Science+Business Media, LLC 2011

During the fall semester 2011, I had the delightful experience of being invited to dinner with the University of Georgia's 2011-12 Senior Teaching Fellows (http://www.ctl.uga.edu/ faculty/ctl_senior_teaching_fellows). This program began in 1987 with a three-year grant from the Department of Education's Fund for the Improvement of Post-Secondary Education (FIPSE); and, at the conclusion of the grant cycle, the demonstrated success of the program led the University to continue it. It now resides in the University's Center for Teaching and Learning and is in its 23rd year. This level of success should be a lesson to funders everywhere: an investment in colleges and universities pays dividends, and sustainability is a high priority for the grantee. However, I am digressing, so back to the story.

The Senior Teaching Fellows program annually supports eight associate or full professors in a year-long program to share ideas about teaching and learning across the disciplines. Through monthly roundtables, guest speakers, a fall retreat, and a small grant (\$2,000 each) to support instructional enhancement in the home department, the fellows are given opportunities for professional and personal renewal. While fellows build and share their pedagogical knowledge, they are also building meaningful faculty relationships outside their units and across a large research campus.

An evening with the fellows was such a delight after spending many hours each day in committee meetings and informal discussions where the topics often are budget cuts, external pressures, lack of faculty and staff raises, the poor economy overall, and increasing regulation from the governing authority. After the dinner, based on the fellows' enthusiasm and commitment and their thoughtful suggestions about improving teaching and learning and academic life on campus, I went straight to the website to learn more about previous participants; it read like a who's who of campus leaders. Now the classic chicken-or- egg dilemma emerged. Were these fellows established campus leaders who were chosen for the program, or did the program create university leaders? It's probably some of both. If it creates leaders, great, and if it rewards leaders, then wonderful! Needless to say, in these difficult times in the academy, I came away believing that the program should have two cohorts next academic year!

L. V. Morris $(\square)$

Institute of Higher Education, University of Georgia, 102 Meigs Hall, Athens, GA 30602-6772, USA

e-mail: lvmorris@uga.edu 
Some of the ideas that emerged included adding a living-learning community in the arts, supporting team teaching to increase cross disciplinary activities, building upper-level seminars like UGA's popular first-year seminars in the First Year Odyssey Program (https:// fyo.uga.edu/), and helping 1st year students make the transition to college overall. The fellows also described a unique experience that entailed going to the School of Art, where the director taught them how to throw a pot (ceramic department) and how this activity placed them in touch with the way students must feel when faced with a new environment and expectations for performance. One described the anxiety he felt because he wanted to do a good job and did not want to be the one who messed up; he realized how our students must often feel this way and what this meant for the learning environment that he was creating. It was touching to hear the depth of concern and affection the fellows held for students and their worries about the pitfalls that will trap many young people, including alcohol abuse and other risky behaviors. It was one of those moments when you wish you could record the conversation for the parents of those first-year, residential students and also for the legislators and members of the system staff and board. Faculty care! They work long hours. They persevere and create with the reality of fewer resources and heavier workloads.

The discussions did not reveal the frustration or unrealistic expectations that can sometimes mark discussions of teaching and learning, which are couched in the recurring theme of how research trumps the importance of teaching in a research university. The fellows saw opportunities and possibilities in their discussions of improving learning and the lives of students in the academy. They engaged in what Johansen (2009) described as "dilemma flipping" in the book Leaders make the future: Ten new leadership skills for an uncertain world. Johansen has suggested that the issues of the future will be complex, changing, and evolving; and unlike "problems," which can be defined and solved, "dilemmas" are ongoing and must be framed and reframed. Accordingly, leaders will define complex, ambiguous situations as dilemmas that are "opportunities" on which they act neither too late nor too quickly. Through sharing their experiences, the fellows were becoming immersed in the dilemmas to identify patterns and to make sense of the dilemmas. Dilemmas are a comfortable space for faculty, for facing dilemmas is what they do daily in and out of the classroom; and they teach students to do the same.

As the year goes on, the fellows will refine their topics and ideas and bring recommendations to the Provost and will take new ideas back to their home departments. By all signs, this cohort will think deeply and make substantive proposals on teaching and learning to the senior administration. If "innovative" ideas emerge from this group, then I will get back to you. In the meantime, best wishes in teaching and learning to all.

\section{Reference}

Johansen, B. (2009). Leaders make the future: Ten new leadership skills for an uncertain world. San Francisco, CA: Berrett-Koehler. 